\title{
THE ROLE OF PRACTICUM FOR EARLY CHILDHOOD TEACHER EDUCATION: THE PERSPECTIVES OF STUDENT TEACHERS
}

\author{
Rita Friães ${ }^{1}$, Dalila Lino ${ }^{2}$, Cristina Parente ${ }^{3}$, Clara Craveiro ${ }^{4}$, Brigite Silva ${ }^{4}$ \\ ${ }^{1}$ Polytechnic Institute of Lisbon, Higher School of Education, CIED, UIDEF (PORTUGAL) \\ ${ }^{2}$ Polytechnic Institute of Lisbon, Higher School of Education, CIED, CIEC \\ (PORTUGAL) \\ ${ }^{3}$ University of Minho, Institute of Education, CIEC (PORTUGAL) \\ (PORTUGAL) \\ ${ }^{4}$ Higher School of Education Paula Frassinetti, CEIED \\ (PORTUGAL)
}

\begin{abstract}
In the last decade with the reforms required by the Bologna process the role of practicum in preservice teacher education has been emphasized, making it a central component of European curricula. It has been observed over the years that this dimension has been mainly approached in terms of organization and supervision processes and cannot be found many studies that focus effectively on what it represents for the actors and its contributions for professional development. This study aims to understand the practicum at pre-service early childhood teacher education. The objectives of the study are: (i) to identify the role of the practicum for professional learning and development of early childhood teachers; (ii) to know the difficulties and critical factors experienced by student teachers at practicum. The methodology used is the mix-method research and data was collected through questionnaires and semi-structured interviews. The participants are early childhood teachers that have graduated in the last three years from different Portuguese Higher Education Institutions. The qualitative data was analyzed through content analyze and descriptive statistic was used to analyze the quantitative data. To ensure confidentiality no information is disclosed without participant's consent and the interviews were transcribed. The results confirm the centrality of practicum for early childhood teachers' professional development. The construction of professional knowledge emerges as one of the main contributions of practicum. Another contribution is the student teachers' awareness of their own strengths and weaknesses in terms of theoretical and practical knowledge. The data also show that the relationships with the educational context and with the different practicum actors (supervisors, cooperating teachers) has a supportive role for student teachers' success. The study points out several difficulties experienced by the student teachers, namely: lack of time to respond to all the academic tasks; the interconnection theory practice; the development of reflection and research skills.
\end{abstract}

Keywords: Practicum, early childhood teacher education, professional development

\section{INTRODUCTION}

Following what occurred at the European Higher Education Area in Portugal, the model of organization of teacher education that qualifies for teaching at the various levels of education has undergone profound changes in recent years, ensuing the suitability of the courses to the Bologna process. Starting in 2007, following the new legal framework for higher education, a new legal framework for preservice teacher education is introduced, which definitively changes the configuration of the training that enables professionals to perform the teaching function, namely in pre-school education and in the 1st and 2nd cycles of basic education. The preservice programs for teachers at these levels of education are organized according to the guidelines of the general legislation governing higher education, namely the Legal Regime of Higher Education Institutions [39] and by the specific legislation that regulates the initial teacher education - Legal Regime of Professional Qualification for Teaching [40], [41].

Specifically, with the new legal framework, preservice teacher education includes two training cycles, establishing a master's degree as a necessary condition for teaching at any level of education. A first cycle, designated as a Bachelor in Basic Education, with a duration of three years, which does not confer any specialization for teaching and that qualifies for entering a second cycle of training for the exercise of teaching in the preschool and 1 st and 2 nd cycle of basic education; a second cycle called 
Master's Degree in Teaching which qualifies for teaching in pre-school, elementary and secondary education. The legislation requires a training of three semesters (90 ECTS) to get a masters' degree in preschool education and a training of four semesters (120 ECTS) to get a masters' degree in 1 st cycle of Basic Education.

Teacher education in Portugal is integrated into the higher education system, being taught by polytechnic and university institutions. It is an area totally regulated by the tutelage, since it is the State who establishes the conditions of access to the programs that qualify for teaching, the definition of the type of courses, the structure of the courses, namely, the training components and the respective ECTS, and the professional profiles. The State also defines the mechanisms for regulating the quality of qualification for teaching, evaluating the quality of programs, and ensuring that future teachers develop the skills and knowledge required to practice the profession [25].

Although the legislation establishes the components of training and their respective weights in the study plans, it leaves room for the courses to be organized according to the conceptions and training models recommended by each higher education institution. Based on the professional profiles of preschool teachers and teachers of other cycles [39], as well as the curriculum of the level of education in which the future teachers will carry out their activity of (in the case of preschool teachers, the so-called Curriculum Guidelines for Preschool Education), the higher education institutions have the autonomy to decide the curricular and elective courses of each curricular component, to select the courses and contents to be taught, the teaching methodologies and the assessment methods for each course [25].

The curricular components of the initial teacher educating programs are now relatively consensual in many countries, establishing that beyond a scientific training in teaching content and a scientific education in Educational Sciences, the education of these professionals should include a dimension of pedagogical practice supervised by higher education institutions, in cooperation with practical institutions (schools), and these partnerships deserve special attention, due to their crucial importance in the process of teacher professionalization. This concern is evident in the Portuguese normative framework that regulates the initial teacher education of preschool, primary and secondary teachers [49]. It should be stressed, however, that the current regulatory framework establishes a clear differentiation between the component of professional practice which should take place in the first cycle of training (undergraduate) and that which should occur in the second cycle, - Initiation to Professional Practice and Supervised Professional Practice, respectively. In fact, only the practice that occurs on the second cycle must be supervised.

Practicum, as part of the teaching curriculum that enables students/future teachers to exercise their professional activity with pedagogical supervision [37] has been recognized in recent years as a key component in initial teacher education, becoming a "flag discipline" of European curricula [34]. According to the literature, practicum in the initial teacher education constitutes a facilitating moment of the learning and professional development of the future teacher, due to the concrete experience in the real contexts of work [8], [13], [18], [20], [22], [24], [26], [28], [[31]. Immersion in professional practice is, in fact, an opportunity to acquire human skills and abilities [10] to build professional knowledge [5], [19], [32], of (re) definition of professional know-how [33]; is a period of supervised, reflected experiential learning [25].

Promoting a permanent liaison between theory and practice [16] practicum constitutes a space-time that acts as a link between the world of work and the learning world [9].

The countless roles and responsibilities of early childhood educators, namely: to promote children's development, respond to the different needs and interests of children, design and implement an integrated curriculum, organize the educational environment, observe, plan and evaluate, working collaboratively with families and communities, negotiating unexpected and challenging situations [36] require these professionals to have a broad and diverse set of knowledge. In this context, it is fundamental that during the training period the student become aware of the different dimensions that constitute the professionalism of an early childhood teacher and acquire a set of professional knowledge and skills that will allow him/her to respond to what will later be required. Thus, practicum assumes a central and fundamental role in the process of becoming an early childhood teacher [8].

The quality of experiential learning that occurs at practicum is influenced by several factors, those more related with the subjects (students) in training, and those more relate to the formative contexts (schools) [29]. Supervision is widely pointed out in the literature as one of the main critical components at this stage of the student's formative process [36]. 
Although the importance of practicum is recognized, both by teacher education policies and literature, there are still few studies that highlight the decisive value of practicum, namely, to show how it contributes to the professional learning and development of prospective teachers. The present study aims to contribute to this discussion.

\section{METHODOLOGY}

The present study is part of a broader research project on practicum of early childhood teachers' preservice training. The main objective of the ongoing project is to understand the practical training processes of early childhood teachers, specifically, to identify the reasons for success, difficulties and problems encountered by student teachers at practicum carried out in infants and toddlers and preschool settings. Another goal of the project is to identify the supervision strategies adopted by the supervisors and the cooperating educators to promote learning and professional development of the student teachers.

The objectives of this study are: (i) to identify the role of practicum for professional learning and development of early childhood teachers; (ii) to know the difficulties and critical factors experienced by student teachers at practicum.

This study used mix methods approach [11], using a combination of qualitative and quantitative methods in data collection and analysis to ensure an in-depth understanding of the phenomenon under study [14].

The first phase of data collection, semi-structured interviews [23] or semi-directives [15] were carried out to a group of 27 early childhood teachers that have recently completed a master in Preschool Education from three higher education institutions in Portugal (one located in Lisbon and two located in the northern region of the country, two of which belong to polytechnic education, one from the private sector and another from the public sector, and one belonging to public university education.) The interviews were recorded, transcribed and the information was submitted to content analysis [2]. A thematic analysis was chosen [2], predominantly inductive, influenced by the theoretical references and by the researchers' perspective on the subject under analysis.

The second moment of data collection was the application of a questionnaire that was sent to a group of early childhood teachers that have recently completed a master in Preschool Education at the three Higher Education Institutions. Twenty questionnaires were devolved and validated.

The dimensions of the questionnaire were defined based on the interview dimensions. In the construction of the items, the data resulting from the analysis of the interviews, the contributions of the literature, the results of previous studies carried out by the researchers [25], and the professional experience of the researchers in the area were considered.

In the construction of the instrument, a set of concerns pointed out in the literature [3], [21], [27] was sought, such as: filling instructions and writing the items clearly, with appropriate language to the respondents and to measure only one question, thus avoiding situations of dubious or misunderstandings.

A first version of the questionnaire was conceived to achieve the defined objectives. The first draft questionnaire was submitted to the appreciation of Higher Education professors, that teach at the master in preschool education and are familiar with the problem under study. This first version was also appreciated by students. Each questionnaire was coded to allow the data to be revised, if necessary.

The data collection was done with the express consent of the participating subjects. The anonymity of the Higher Education Institutions and of the participants was also guaranteed.

This article presents the results obtained through the content analysis of the interviews and the statistical descriptive analysis of the questionnaires. 


\section{RESULTS}

\subsection{Content data analyze of interviews}

The results of the interview content analysis are presented below.

Table 1. Contributions of practicum.

\begin{tabular}{|c|c|}
\hline Indicators & Registration Units (examples) \\
\hline $\begin{array}{l}\text { Applying on practice the theory } \\
\text { learned during theoretical training }\end{array}$ & $\begin{array}{l}\text { Practice gives us the possibility of trying to apply the theories. It is the } \\
\text { possibility to apply to the real contexts all those theories that we've learned } \\
\text { (SA) }\end{array}$ \\
\hline $\begin{array}{l}\text { Becoming aware of the } \\
\text { importance of theoretical training }\end{array}$ & $\begin{array}{l}\text { I think that practice is fundamental to realize that what we've learned in } \\
\text { theory makes perfect sense and that everything we've learned is } \\
\text { fundamental. (VN) }\end{array}$ \\
\hline Developing of planning skills & $\begin{array}{l}\text { One of the vital things that l've learned at practicum was that is essential to } \\
\text { change our planning and realize the importance of emergent planning. (VN) }\end{array}$ \\
\hline $\begin{array}{l}\text { Developing competencies to } \\
\text { manage social conflicts }\end{array}$ & $\begin{array}{l}\text { Practice allows us to learn how to mediate social conflicts with young } \\
\text { children. (VN) }\end{array}$ \\
\hline $\begin{array}{l}\text { It leads to the awareness of the } \\
\text { importance of reflection }\end{array}$ & $\begin{array}{l}\text { I realized that it is so important to reflect that today, in my professional } \\
\text { activity, I continue to have my notepad and to register everything, so I can } \\
\text { reflect at the end of the day. It is essential in our practice. (RT) }\end{array}$ \\
\hline $\begin{array}{l}\text { Facilitates awareness of the } \\
\text { importance of problematizing } \\
\text { practice }\end{array}$ & $\begin{array}{l}\text { The research was fundamental because it leads us to realize the } \\
\text { importance of questioning the practice, trying to find solutions (DA) }\end{array}$ \\
\hline $\begin{array}{l}\text { It promotes the development of } \\
\text { reflection skills }\end{array}$ & $\begin{array}{l}\text { Reflection is a way to review the experience, to learn from it and, } \\
\text { consequently, to develop new understandings and appreciations. (S) }\end{array}$ \\
\hline $\begin{array}{l}\text { Allows the development of know- } \\
\text { how }\end{array}$ & $\begin{array}{l}\text { Practicum is a shift, because we can know how to do it, but it is during } \\
\text { practice that we learn how to do it. For example, conflict resolution ... we } \\
\text { know in theory how it is done, but when two children are involved in social } \\
\text { conflicts we have the theory and that does not always work, it is in that } \\
\text { moment that we learn, there are things that we can only understand when } \\
\text { they happen in real situations. (VN) }\end{array}$ \\
\hline $\begin{array}{l}\text { It leads to awareness of the need } \\
\text { to act on the moment }\end{array}$ & $\begin{array}{l}\text { To act on the emergent, to see and act, because we cannot stay there } \\
\text { waiting, seeing and thinking without acting. (SA) }\end{array}$ \\
\hline $\begin{array}{l}\text { Know and manage pedagogical } \\
\text { documentation }\end{array}$ & $\begin{array}{l}\text { Throughout practicum much learning occurred, namely to know which } \\
\text { documents we can use later in our professional practice and how to use } \\
\text { them (P1) }\end{array}$ \\
\hline $\begin{array}{l}\text { Improve the capacity to deal with } \\
\text { Special Needs children }\end{array}$ & $\begin{array}{l}\text { Learn how to develop certain activities with children with Special Needs. } \\
\text { (P2) }\end{array}$ \\
\hline $\begin{array}{l}\text { Improve ability to respond to } \\
\text { children's needs }\end{array}$ & $\begin{array}{l}\text { What I can mainly emphasize was to learn how to respond appropriately to } \\
\text { the group and the individual child. (P3) }\end{array}$ \\
\hline Manage transition times & $\begin{array}{l}\text { I've learned in practice how to work and do activities during transition times, } \\
\text { because they are very important moments. (P4) }\end{array}$ \\
\hline $\begin{array}{l}\text { Improve the knowledge about the } \\
\text { ECE professional contexts }\end{array}$ & $\begin{array}{l}\text { Understand the organization and all the dynamics of a preschool setting. } \\
\text { (P5) }\end{array}$ \\
\hline $\begin{array}{l}\text { Appropriation of new pedagogical } \\
\text { strategies }\end{array}$ & to children \\
\hline
\end{tabular}

Table 1 highlights the main contributions of practicum that emerge from the discourse of the participants interviewed. In fact, the various contributions emphasize the idea of practicum as a space and time for learning and professional development, which highlights the development of planning skills, management of the cooperating teacher documents (e.g. pedagogical and educational project), group and time management, reflection skills, interaction with the group (namely in the interaction with children with Special Needs). It is also clear from the interviewees' discourse the idea of awareness related to the practice of the early childhood teacher essential for the development of their 
pedagogical action - the importance of problematizing practice and reflection in and about it. Practicum still appears as a place of theory-practice relationship, making possible the application of theories learned during theoretical education and giving meaning to these theories.

Finally, the contact with the professional practice should also be emphasized, because of its role leading also to a deepen knowledge about the characteristics of the professional contexts of the early childhood teacher.

\subsubsection{Difficulties experienced during practicum}

Table 2 presents the main difficulties and challenges experienced by student teachers in practicum.

Table 2. Difficulties experienced during practicum.

\begin{tabular}{|l|l|}
\hline \multicolumn{1}{|c|}{ Indicators } & \multicolumn{1}{|c|}{ Registration units (examples) } \\
\hline $\begin{array}{l}\text { Difficulties in handling } \\
\text { documentation }\end{array}$ & $\begin{array}{l}\text { The documentation that the preschool teacher must do, for example, the } \\
\text { curricular project, I had never had much contact with and it, was difficult for me. } \\
\text { (OJ) }\end{array}$ \\
\hline $\begin{array}{l}\text { Manage time (given the } \\
\text { number of requests from } \\
\text { theoretical training) }\end{array}$ & $\begin{array}{l}\text { The most difficult thing is to be able to deal with everything, I felt this difficulty, a } \\
\text { difficulty to manage the time (JO) }\end{array}$ \\
\hline Manage time of activities & $\begin{array}{l}\text { It was a little hard when I scheduled an activity for } \mathrm{X} \text { and then it took longer or } \\
\text { less time, it was not easy to manage. (RT) }\end{array}$ \\
\hline $\begin{array}{l}\text { Lack of preparation to deal with } \\
\text { children with Special Needs }\end{array}$ & $\begin{array}{l}\text { I felt some difficulties in knowing how to react to these children, how to act with } \\
\text { these children as a future early childhood teacher. For example, when there } \\
\text { were large group moments and the child did not want to be seating with the } \\
\text { group, I did not know very well what I should do, when we developed an activity } \\
\text { and I saw that the child was not included in the activity, it was not involved. (VN) }\end{array}$ \\
\hline $\begin{array}{l}\text { Take ownership of the } \\
\text { reflective process and carry out } \\
\text { weekly written reflections }\end{array}$ & $\begin{array}{l}\text { The main challenge was to reflect on what went well and poorly on all the } \\
\text { proposals, as well as reflect on why certain situations did not go so well. Also, to } \\
\text { maintain a reflexive attitude from the beginning to the end of practicum, which at } \\
\text { the beginning I found very difficult. (J) }\end{array}$ \\
\hline $\begin{array}{l}\text { Consistent educational } \\
\text { philosophy, visions, } \\
\text { approaches, and beliefs }\end{array}$ & $\begin{array}{l}\text { My image of children and my vision about early childhood education were so } \\
\text { different from the ones of the context of practice and that became complicated. } \\
\text { This difficulty made me feel uncomfortable to talk with the cooperating teacher } \\
\text { about my doubts, worries, my fears, fears, my anguish. (C) }\end{array}$ \\
\hline $\begin{array}{l}\text { To act on the moment } \\
\text { about it. (SA) }\end{array}$ \\
\hline
\end{tabular}

In the participants' speech, difficulties of a different order stand out. There are some difficulties that are more directly related to the theoretical courses and other more related to practicum. Participants mention that theoretical courses demand too many assignments. At practicum they have experienced several difficulties, namely: managing time for educational activities; to follow the pedagogical and curricular project of the cooperating teacher; to respond appropriately to children with Special Needs; to be consistent with their own educational philosophy, visions, beliefs, pedagogical approaches developed during the theoretical education and the ones adopted by the practicum institution and cooperating teacher; to develop a reflexive attitude towards practice, such as carry out the weekly written reflections.

\subsubsection{Critical factors}

Table 3 shows several critical factors that can impact on professional learning and development of student teachers that occurred at practicum. 
Table 3. Critical factors.

\begin{tabular}{|c|c|}
\hline Indicators & Registration units (examples) \\
\hline $\begin{array}{l}\text { Support at the } \\
\text { internship contexts }\end{array}$ & $\begin{array}{l}\text { I was very lucky with the contexts in which l've done practicum, both in day care and in } \\
\text { preschool, I felt very welcomed. (OJ) }\end{array}$ \\
\hline $\begin{array}{l}\text { Support of cooperating } \\
\text { teacher }\end{array}$ & $\begin{array}{l}\text { The support and guidance of the cooperating teacher throughout my internship and the } \\
\text { moments at the end of the day to share my doubts, difficulties and to plan together was } \\
\text { fundamental to developing professional learning. In addition, the support of the } \\
\text { cooperating teacher was fundamental to know better the educational context, namely } \\
\text { the group of children and to create a very positive relation with children's parents. }(\mathrm{J})\end{array}$ \\
\hline $\begin{array}{l}\text { Support of } \\
\text { supervisor }\end{array}$ & $\begin{array}{l}\text { The supervisor, besides being an incredible support, was important to guide me with } \\
\text { the sense and confidence in my practice. She provided me with various materials to } \\
\text { support all my actions, as well as gave me advice for a more appropriate practice, as } \\
\text { well as challenging myself with various questions that still make me think and reflect. } \\
\text { (W) } \\
\text { It is very important to have someone to guide us, to tell us what is not right, to talk to } \\
\text { us, to integrate us, to challenge us. (SA) }\end{array}$ \\
\hline $\begin{array}{l}\text { Support } f \\
\text { teaching } \\
\text { practicum }\end{array}$ & $\begin{array}{l}\text { I knew that if I had any questions or difficulties, I could go to and ask for the support of } \\
\text { the teachers and the staff who would help me, give me no answers, but let me get to } \\
\text { the information. That was fundamental, I think it has a very important role. (VN) }\end{array}$ \\
\hline $\begin{array}{l}\text { Possibility } t \\
\text { at the parer }\end{array}$ & $\begin{array}{l}\text { es was very important, because I feel that I } \\
\text { are not prepared. (DA) }\end{array}$ \\
\hline $\begin{array}{l}\text { Daily records and } \\
\text { reflections }\end{array}$ & $\begin{array}{l}\text { For me one of the most important things in practice was to keep track of what was } \\
\text { happening on a daily basis, take notes of the most important things that were } \\
\text { happening, situations that had caused me some difficulty and that I was not prepared to } \\
\text { answer, what was interesting to me and what caused me difficulty and then what I did } \\
\text { was to reach the end of the day I read my records and reflected on it and sought to } \\
\text { realize "here I acted well or I could have acted this way." She pondered and then went } \\
\text { to look for answers to that. (VN) }\end{array}$ \\
\hline $\begin{array}{l}\text { The weekly } \\
\text { about the pr }\end{array}$ & $\begin{array}{l}\text { By reflecting on what happened during the week I was able to understand the evolution } \\
\text { of my learning, as well as to identify and support with intentionality the interests and } \\
\text { needs revealed by the children. It was also essential the challenge to connect this } \\
\text { reflection with the theories which allowed me to understand endless situations, as well } \\
\text { as to direct my pedagogical practice. (S) }\end{array}$ \\
\hline $\begin{array}{l}\text { Sharing and exchanges } \\
\text { between peers }\end{array}$ & $\begin{array}{l}\text { A very important support strategy was undoubtedly the peer dialogue, as it allowed me } \\
\text { to reflect and analyze what I could improve in my educational practice throughout the } \\
\text { internship. (E) }\end{array}$ \\
\hline
\end{tabular}

The critical factors pointed out by the participants, that may constitute possible key factors of the development of practicum and therefore of the professional learning and development, show the central role of supervision in this process, namely the support given by the cooperating teachers and supervisors (orientation, availability of resources and feedback, sharing of experiences) and the importance of written reflection. The welcoming reception of the cooperating institution, the educational team and the support of the staff are other aspects that seem to facilitate practicum and therefore contribute for student teachers' success.

\subsection{Statistical descriptive analysis of the questionnaires}

This section presents the most relevant data resulting from the statistical analyze of the questionnaire and that are related to the contributions of practicum.

Table 4 highlights the contributions of practicum most mentioned by the participants. It was taken by criterion to highlight those who were referred by at least a quarter of the sample. Participants were asked to identify and prioritize the five items they considered most relevant given their own experience from a set of 27 items. 
Table 4. Frequency of the items that appear in the first five positions.

\begin{tabular}{|l|c|}
\hline \multicolumn{1}{|c|}{ Items } & Frequency \\
\hline 1. Develop the capacity for reflection in and on practice & 12 \\
\hline 28. Deepen knowledge and develop skills on pedagogical models / approaches & 7 \\
\hline 6. Know the professional "Self" & 6 \\
\hline 14. Develop an enquiry attitude about the practice & 6 \\
\hline 3. Deepen the professional knowledge & 5 \\
\hline 20. Develop observation skills & 5 \\
\hline
\end{tabular}

Of the 27 items presented to participants as possible contributions of practicum for learning and professional development, there were six that stood out the most considering the number of choices. The development of reflexive skills is the most mentioned contribution, bringing together the consensus of $60 \%$ of the respondents.

\section{DISCUSSION}

Although the characteristics of the study do not allow generalizations, the collected data contribute to the understanding of the role of practicum in the education of early childhood teacher education. In fact, on the discourse of the participants interviewed emerges the importance of the inexorable role of practicum for early childhood teachers' professional development. The data support the key role played by the immersion of the student teachers in professional practice, as is referred in the literature on teacher education [8], [9], [22], [25], [31], [32], [33].

Students relate practicum with the development of professional competences and fundamental awareness of the professional performance of the early childhood teacher, stressing the skills of planning, managing documents to support the daily work of the early childhood teacher, managing the group of children and time, acting on the moment, problematizing practice and reflect in and on practice, giving relevance to the reflection role. Thus, practicum is revealed as a space and time of professional (re) configuration, socialization and professional development [16], [35], [36].

In the participants' discourse, practicum emerges as a theory-practice link, [7], [30], since it is during practicum that the student teachers have the possibility to apply what they have learned during the theoretical training, and to give meaning to this theory.

However, the experience of practicum poses a set of challenges and difficulties for student teachers. The difficulty in managing the time to respond to the requests of the different theoretical courses and to answer the different tasks required by practicum, the difficulty in handling the documentation to support the action of the early childhood teacher (e.g. educational project), to manage the time during the children's activities, the management of the group, namely conflicts resolution, the weekly written reflections and the consistency of the educational philosophy, visions, pedagogical approaches and educational beliefs, are some difficulties pointed out by the students, which confirm the results of previous studies [25].

The data show the existence of a vast set of factors that may influence the development of practicum, facilitating or hindering student learning and professional development. The role of supervision, namely the support provided by the main actors of the supervisory process - institutional supervisor and cooperating teacher, is pointed out by the students as central for their professional learning and development [1], [37]. It also supports the legislation that regulates the initial teacher education in Portugal [41], which requires cooperating teachers to have a minimum of five years of professional experience and identifies as a preferred criterion to be holders of training in supervision [32].

The data also point out the acknowledgment of critical reflection as a fundamental component of practicum, being considered as the basis for the knowledge of the "professional self" and for learning during this period [10], [38].

\section{ACKNOWLEDGEMENTS}

This study is part of the research project intitled $A$ formação prática dos educadores de infância e dos professores do $1^{\circ}$ e $2^{\circ}$ ciclo do ensino básico/ ESEXL/IPL-CIED/2016/A10. 


\section{REFERENCES}

[1] I. Alarcão \& J. Tavares, Supervisão da prática pedagógica: uma perspetiva de desenvolvimento e aprendizagem, $2^{\mathrm{a}}$ ed, Coimbra: Almedina, 2003.

[2] L. Bardin, Análise de conteúdo, Lisboa: Edições 70, 2009.

[3] J. Bell, Como realizar um projecto de investigação, Lisboa: Gradiva, 1997.

[4] R. Bogdan, R, \& S. Biklen, Investigação qualitativa em educação. Uma introdução à teoria e aos métodos, Porto: Porto Editora, 1994.

[5] D. P. Britzman, Practice makes practice:a critical study of learning to teach, Albany, New York: Suny, 1991.

[6] A. Bryman \& D. Cramer, Análise de Dados em Ciências Sociais: Introdução às técnicas utilizando o SPSS, Oeiras: Celta Editora, 1992.

[7] J. S. Bruner, Cultura da Educação, Lisboa: Edições 70, 2000.

[8] S. Caires, "Vivências e percepções do estágio pedagógico: contributos para a compreensão da vertente fenomenológica do «tornar-se professor»", Análise Psicológica, vol. 24, n. ${ }^{\circ 1}$, pp.87-98, 2006.

[9] R. Canário, "A prática professional na formação de professores", In Formação profissional de professores no ensino superior (B.P. Campos org), pp. 31-45, Porto: Porto Editora, 2001.

[10] D. Contreras, "Ser e saber en la formación didáctica del profesorado: una vision personal", Revista Interuniversitaria de Formación del Profesorado, vol. 68, n. ${ }^{\circ}$ 24, pp.61-81, 2010.

[11] J. W. Creswell, Research Desing: Qualitive, Quantitative and Mixed Approaches. University of Nebraska-Lincoln: Sage, 2014.

[12] M. Damas \& J. Ketele, Observar para avaliar, Coimbra: Almedina, 1985.

[13] L. Darling-Hammond, "Teacher education and American future", Journal of Teacher Education, vol. 61, n. ${ }^{\circ} 1-2$, pp. 35-47, 2010.

[14] N. K. Denzin \& Y. Lincoln, "Introduction:Entering the field of qualitative research", In Strategies of qualitative inquiry (N. Denzin\& Y. Lincoln org), pp. 1-34, Thousand oaks: Sage Publications, 1998.

[15] N. K. Denzin, "The research act, Englewood Cliffs", NJ: Prentice Hall, 1984.

[16] M.A. Flores, A.M. Veiga Simão, R. Rajala \& A. Tornberg, "Possibilidades e desafios da aprendizagem em context de trabalho. Um estudo internacional", In Aprendizagem e desenvolvimento professional de professors: contextos e perspectivas (M.A. Flores\& A.M. Veiga Simão org), pp. 119-151. Lisboa: Edições Pedago, 2009.

[17] W. Foddy, Constructing question for interviews and questionaires. Theory and practice in social research, Cambridge: Cambridge University Press, 2003.

[18] J. Fuhrlog \& T. Maynard, The mentoring of student teachers, London: Rooutledge, 1995.

[19] C. Gervais \& P. Desrosiers, L'école, lieu de formation d'ensignants. Questions et repères pour l'accompagnement de stagiaires, Canada: Les Presses de l'Université de Laval, 2005.

[20] C. D. Glickman, S. P. Gordon \& J. M. Ross-Gordon, Supervision of instruction: a developmental approach, Boston: Allyn \& Bacon, 1998.

[21] M. M. Hill \& A. Hill, Investigação por questionário. Lisboa: Edições Silabo, 2005.

[22] D. A. Kolb, Experiencial learning, Englewwod Cliffs, N.J.: Prentice Hall, 1984.

[23] S. Kvale, Interviews: An Introduction to qualitative research interviewing, Thousand Oaks: Sage Publications, 1996.

[24] J. Lave \& E. Wenger, Situated learning: Legitimate peripheral participation, New York: Cambridge University Press, 1991.

[25] D. Lino, C. Parente \& F. Vieira," Inside the practicum...: Crossing the visions of the actors", 10th Annual International Conference of Education, Research and Innovation, pp. 5215-5223, 2017. 
[26] D. McNamara, "The influence of student teachers' tutors and mentors upon their classroom practice: An exploration study", Teaching and Teacher Education, vol. 11, n. ${ }^{\circ}$ 1, pp. 51-61, 1995.

[27] J. M. Moreira, Questionário: Teoria e prática. Coimbra: Almedina, 2004.

[28] J. Oliveira-Formosinho, "Em direcção a um modelo ecológico de supervisão de educadores de infância", Inovação, vol. 10, n. ¹, 89-110, 1997.

[29] T. Perez-Roux, "Professionalisation et construction identitaire Durant la formation initiale: le cas des enseignants stagiaires du second degré", In Comment les enseignants apprennent-ils leur métier? (R. Wittorski \& S. Briquet-Duhazé org), pp. 49-80, Paris: L'Harmattan, 2008.

[30] J. P. Ponte, "Os desafios do Processo de Bolonha para a formação inicial de professores", Revista de Educação, vol.14, nº.1, pp19-36, 2006.

[31] L. Shulman, The wisdom of practice. Essays on teaching, learning and learning to teach, San Francisco: Jossey Bass, 2004.

[32] K. Smith \& L. Lev-Ari, "The place of the practicum in pre-service teacher education: the voice of the students", Asia Pacific Jounal of Teacher Education, vol. 33, n. ${ }^{\circ}$ 3, pp. 289-302, 2005.

[33] M. R. Serrano, "El practicum y la formación en competências del Maestro de Educación Infantile en España", Revista Iberoamericana de Educación, vol.42, n. ${ }^{\circ 7}$, pp.1-14, 2007.

[34] E. Starkie," La formación de los docents a través del practicum", Revista Interuniversitaria de Formación del Profesorado, vol. 20, n. ${ }^{\circ}$ 3, pp.121-136, 2006.

[35] T. Vasconcelos, Prática pedagógica sustentada: Cruzamento de saberes e de competências, Lisboa: Colibri, 2009.

[36] S. W. Wee, E. Weber, \& S. Park, "Early childhood practicum students' professional growth in the USA: areas of confidence and concern", International Journal of Early Years Education, vol. 22, nº 4 , pp. 409-422, 2014.

[37] M. Zabalza, Competencias docentes del profesorado universitario.Calidad y desarrollo professional, Madrid: Narcea, 2003.

[38] K. Zeicnher, A formação reflexiva de professores, ideiase práticas, Lisboa:Educa, 1993.

[39] Decree-Law no. 200/2001, of August 30 and Decree-Law no. 201/2001, of August 30.

[40] Decree-Law no. 43/2007, of February 22.

[41] Decree-Law no. 79/2004, of May 12. 